\title{
北西ドイッ顎外科学教室におけるエナメル上皮腫
}

\section{4 例の臨床的および病理学的研究}

第 2 報 療法, 予後および組織学的所見について

\author{
清 水 正 嗣 \\ 東京医科歯科大学口腔外科学教室（主任：上野正教授) \\ ハンブルグ大学, 北西ドイツ顎外科学教室客員医員 \\ (指導 : Karl Schuchardt 教授)
}

(昭和 39 年 1 月 15 日受付)

Clinical and Pathological Studies of 54 Cases of Ameloblastomas, Treated at the Nordwestdeutsche

Kieferklinik, University of Hamburg.

Part II : Treatment, Results and Histological Findings

\author{
Masatsugu Shimizu \\ Dept. of Oral Surgery, School of Dentistry, Tokyo Medical and Dental University \\ (Director: Prof. T. Ueno) \\ Nordwestdeutsche Kieferklinik in Hamburg \\ (Director: Prof. K. Schuchardt)
}

\section{I. まえがき}

さきに発表した第 1 報 学部付属病院, 北西ドイッ顎外科学教室において 1946 年 2 月から, 1962 年 3 月迄の期間にとりあ つかわれたエナメル上皮腫 54 例について，臨床 統計的観察，ならびにX線像所見についてのべた が, 今回はその療法と予後および組織学的所見に ついて報告する。

特にその病理組織学的所見については, エナメ ル上皮腫の宮崎一石川の分類 ${ }^{23}$ 3) 9 適用と共に， 悪性エナメル上皮腫の追求を行い, さらに得られ た結果を, 既発表の東京医科歯科大学口腔外科学 教室(以下医歯大口外と略す), および同病理学教 室の研究業績 $\left(1957^{3)}, 1958^{5)}, 1959^{4)}, 1962^{6)}\right.$, $1963^{7)}$ と対比, 検討した。

\section{II. 療法および予後}

エナメル上皮腫の治療原則として, 北西ドイッ 顎外科は, 腫瘍の存在する下影の十分なる切除, 必要な場合には関節離断手術を含めた根治手術を 採用実施している。老令の患者あるいは重篤なる 副次疾患をもつている患者を除き, 搔爬の如き姑 息療法は行なつていない。

本報告 54 症例に対して採られた療法を分類す ると次の如くである。

47 例に手術療法を行ない, このうち 30 例には 関節離断を伴つた顎骨の広範なる切除が実施され

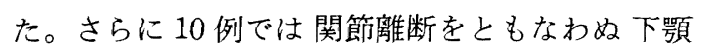
骨切除のみが行なわれ, そのうち 2 例は, 術後 Radium 各 $6,000 \gamma$ の後照射をうけた。他の 7 例で は局所的腫瘍摘出を行なつた。これら手術療法を 
うけた 47 例のうち 5 例には, 骨の前移植が行なわ れ, 7 例には術後 $1 \sim 2$ 年で顔面下顎切除欠損部の 修復のため, 自家腸骨稜から採取せる骨片による 形成術が行なわれた。全体のらち23 症例には, 副 木, 特にSchuchardt 法による即重レジン添加金属 弧線副子 ${ }^{8}$ が装着され，その際大部分の症例には 下顎滑面板を用意し，下頷の偏位防止ならびに術 後の安静位保持に役立てた。

手術療法を行なわなかつた 7 例中 4 例は，その 高令あるいは他藏器の疾患の故に保存的療法をう けた。そのうちの 1 例はX X線 $4000 \gamma$ の照射をう けた。その他の 3 例は診断のみであつた。

以上 54 症例中，外科手術療法にゆだねられた 47 症例の予後成績は次の如くである。

1962 年 10 月 1 日現在において, 47 症例中 31 例 注 5 年以上経過しており，16 例は 5 年以内であつ た。

5 年以上経過した 31 例について：

18 例は再発なし—うち 3 例には，以前に再発の

ため数度の再手術施行（うち1例は $6000 \gamma$ の

Radium 照射)。

1 例は 5 年とさカ月後に腫瘍の進展のため, 75 歳 で死亡。同腫瘍は術後 3 年目に側頭部, 多分硬 脳膜をふくめて再発進展したもの。

8 例は，予後観察に来院せず。

2 例は, 術後の併発症のため死亡。

2 例は，患者の家族からの手紙によつて死亡が通

知されたが原因不明 (うち 1 例には，6000 rの

Radium 照射)。

5 年以内の 16 例について :

12 例は再発なし。

4 例は予後観察のために来院せず。

以上を総括すると，手術療法の治療成績として は，31 例についてその 5 年絶対生存率において $61 \%$ であつた。また，上述の 手術療法群全 47 症 例中, 再発を起こしたものは 4 例，9\%であつた。

保存的療法をうけた 4 症例では, 80 歳男性の 1 例が， 2 年と 3 力月間再発なく生存を確認された 以外は予後不明であつた。

\section{III. 組織学的所見}

エナメル上皮腫の組織像は，かなり幅の広、多 様性を示し，それ故種々の組織学的分類がなされ ている。

本邦に扔いては，宮崎・荒井 ${ }^{2)}$ がエナメル上皮 腫をその分化，成熟度に応じて第 I 型より，IV型 迄に分類した。しかし石川の意見" によると，こ の分類の第IV型はエナメル上皮線維腫と同一であ り，それ故混合腫瘍の 1 つとみなされる。石川は さらにこれら而型の他に，悪性エナメル上皮腫お よび，いわゆる腺エナメル上皮腫を別項におく分 類をおこなつた。おたくしは，この石川の分類に したがつて北西ドィッ䫟外科のエナメル上皮腫 54 例の組織標本を観察検討し，分類することを試 みた。

本研究の分類実施のため，わたくしは試験切除 により採取された小組織片のみでなく，手術によ つて切除, 採取された腫瘍組織もまた組織学的に 検索した。症例によつては, 必要で可能な場合, 異なつた腫瘍組織部分から切り出しを行ない，全

表 1 組織学的分類

\begin{tabular}{|c|c|c|c|c|}
\hline & 曈胞型 & 混合型 & 充実型 & 計 (\%) \\
\hline 型 & & 1 & & $1(3)$ \\
\hline 型 & 4 & 3 & 2 & $9(28)$ \\
\hline III 型 & 16 & 3 & 2 & $21(66)$ \\
\hline 腺エナメル上皮腫 & 1 & & & $1(3)$ \\
\hline 計 $(\%)$ & $21(6$ & $7(22)$ & $4(12)$ & 32 \\
\hline
\end{tabular}

体の客観的な組織像判定をするために新たに標本 を作製, 観察した。いくつかの症例では, 確定診 断を下すに十分な標本資料を得ることが出来ず， その場合, それら症例を今回の研究から除外せざ るを得なかつた。

かくして，54 例中 32 例に本分類の 適用を行な うことが出来た。同時にまた，肉眼所見，X線像， 組織像所見にもとづいて襄胞型と充実型との従来 の分類も実施した。その結果抢よび両分類の関倸 を示すものが表 1 である。

全体として第而型がもつとも多く（21 例，66 
\%)，I 型および腺エナメル上皮腫がもつとも少 なかつた(各 1 例， $3 \%$ )。第而型の中では囊胞型 が最も多く，21 例中に 16 例がみられた。本分類 適用の 32 症例中 21 例は単胞あるいは多胞性囊胞 型 $(66 \%) 、 4$ 例は充実型 $(12 \%)$ ，そして 7 例が 混合型 (20\%)であつた。囊胞形成の傾向は，組 織学的に高度に分化した腫瘍程強いといわれてい るが，本研究においても，その第而型におけるよ りも，第I型において充実型の高い百分率がうか がわれたが例数少く，推計学的有意差はみられな い。

病宩部埋伏歯の存在は, 第而型に頻発する点特 徵的である゙といわれているが，本症例群中，そ の 9 症例に各 1 歯ずつの埋伏歯がみられたが，そ のうち, 型の分類不能の 1 例と, 左上顎犬歯部に みられた腺エナメル上皮腫の 1 例計 2 例を除き， すべて第而型に属した。

\section{悪性エナメル上皮腫について :}

エナメル上皮腫は一般に良性腫瘍の 1 型とみな されている。しかし時にはまた悪性腫陽として観 察報告されている。エナメル上皮腫はしばしば再 発するが，再発の成立機転は腫瘍の本体よりもむ しろ治療法が姑息的であつたか，根治的であつた かに関連しており，直ちに悪性を意味するとはい いがたい。すなわち悪性の基準としては，組織学 的異型像, 明らかな浸潤性発育, 転移形成があげ られる゙。气机ら各事項を考慮して 54 症例を追 求したが，1例に疑問を抱かされた他，組織学的 にも臨床的にも悪性症例を確定できなかつた。

ここにのべる疑問症例は, 35 歳男性, 1956 年 11 月 13 日入院し, 同 30 日エナメル上皮腫のため関 節小頭を含めて下顎骨片側切除手術をうけたもの である。その主腫瘍組織は典型的なエナメル上皮 組織像を示し，石川分類 ${ }^{3)}$ のIII型であつた(図 1)。 術後経過良好で 12 月 15 日退院したが, 1958 年 1 月より1961 年 8 月迄反覆再発し, 6 回の手術を うけた。腫瘍の拡がりは, 左側顎下領域から上顎 結節，翼状窩，卵円孔，正円孔に達し，一方蝶形 骨側方より眼窩裂溝，同側壁にもおよんでいた。 臨床的に腫瘍は強い浸潤性発㕕を示し, 組織学的

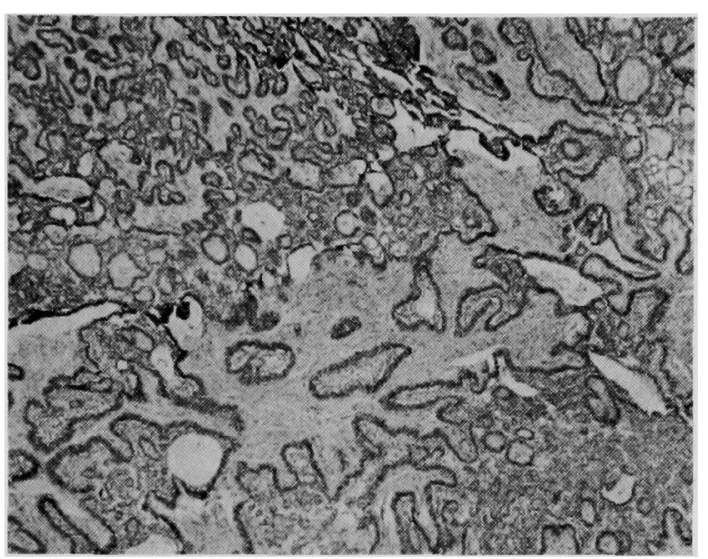

図 1 主腫瘍の組織像, 大部分は典型的な エナメル上皮腫像を呈すが，一部， 基底細胞腫様

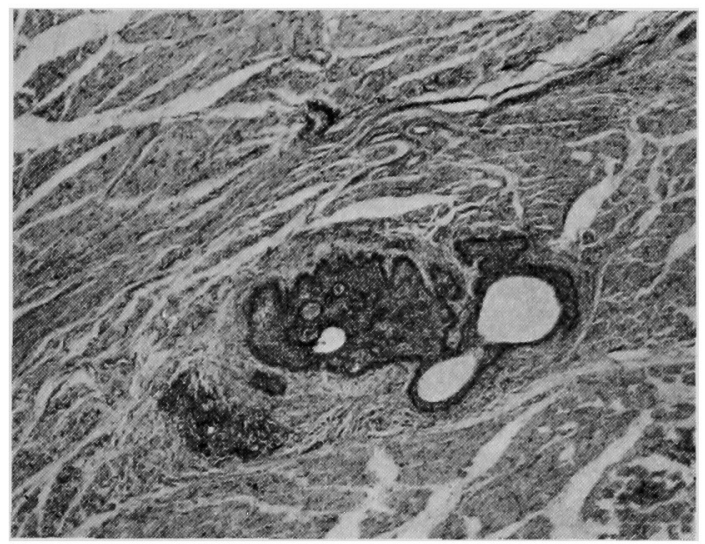

図 2 側頭筋中に浸潤せる腫瘍病巣の組織像

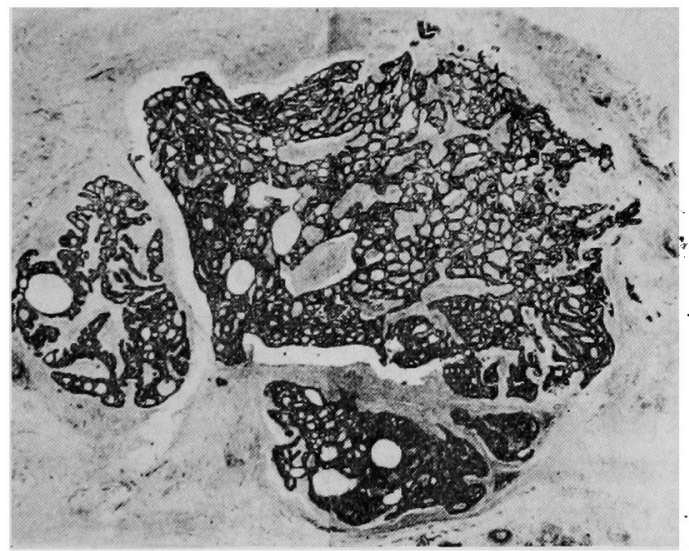

図 3 煩部再発領域の結節性腫瘍, 主腫瘍（図 1）と類似の組織像を示す。 
にもまた臨床像に対応する所見を呈した。すなわ ち，1958 年 9 月 11 日，2回目の再発手術に際し ての組織検査で, 細胞学的異型性はみられないが 側頭筋中に浸潤せる腫瘍の発育が観察された（図 2)。1961 年 9 月 20 日, 最後の再発腫瘍摘出手術 が行われた。その組織学的所見として, 頓部再発 領域に主腫崵から分離して結合組織に被覆された 腫瘍病巣がみいだされ, 正常組織中に, 深く進展 増殖し結節を形成していた（図 3)。

その後患者は 1962 年 12 月迄再発を起こさずに いるが, 卵円孔部に神経痛椂疼痛を訴え, 切断端 神経炎が疑われている。

本症例の場合, 転移形成ならびに細胞学的悪性 像はみられて抢らず，悪性エナメル上皮腫として は確定されない。しかし初回療法が関節小頭を含 めた下顎の根治切除手術であつたにも拘わらず， 多数回の再発を生じた。これら経過を通観すると その腫瘍発育の性質は全く良性とは云、難く，か なり異型性と呼ぶべきかと考えられる。一方その 組織像は典型的なエナメル上皮腫であり，石川分 類の第而型に属し，また 1956 年の初頭から 5 年以 上経過した時点の再発腫瘍組織においても, 殆ど 名付けるべき異型性変化を示さなかつた。本例の 再発がなんら悪性を意味しないとしても，その腫 瘍組織所見はエナメル上皮腫の一種の浸潤性発育 を示した点に関心を抱かされ，今後な打㛜重に予 後追求を必要とする症例と考える。

\section{IV. 総括・考按}

1. 療法と予後について

エナメル上皮腫が再発を起こしやすいことは， くりかえし論じられているが, その頻度をみると, Robinson $^{9}$ は 379 例中 119 例, $32 \%$, Small 他 ${ }^{10)}$ は，359例中 121 例，33\%を報告している。平出 ${ }^{5)}$ によると，115 例中 38 例， $33 \%$ が 再発症例とし て医歯大口外を受診している。

本報告症例群中, 外科的に処置された 47 例の らち再発がみられたものは 4 例，9％であつた。 エナメル上皮腫の予後検討に際して, 5 年生存で は不十分との意見もあるが，一応 5 年絶対生存率
を求めると $61 \%$ \%でった。

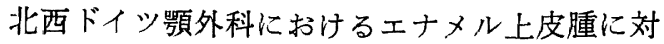
する治療方針は，医歯大口外のものと原則的に一 致して, 根治的切除手術が主体である。一般的に エナメル上皮腫は高い組織学的分化度を示すの で，放射線に対しては低い感受性をもつ。それ故 本疾患に対する放射線療法が副次的治療手段とし てのみ採用されている点は，両教室の治療方針に おいて同様である。両教室間の唯一の相異とし て, 医歯大口外では術後の顔面変形に対する骨移 植形成術を, 主に腫瘍摘出後直ちに行なうのに対 し, 北西ドイツ顎外科では原発病巣がしばしば感 染巣であることから考えられる感染炎症の危険防 止のため, 約 $1 \sim 2$ 年後に 骨移植形成手術を行な う点である。

\section{2. 組織学的所見}

組織学的にエナメル上皮腫は, 歯胚の上皮性成 分に類似の実質と, 結合組織性の間質とから成り 立つており，その広、変異を示す組織像から種々 の研究・分類 ${ }^{11}{ }^{12}$ が行なわれている。わたくしは, 石川の分類 ${ }^{3)}$ に従つて十分な材料の得られた 32 症 例を観察し, I, II, III 型, 悪性エナメル上皮腫 およびいわゆる腺エナメル上皮腫に分類すること を試みた。その結果(表 1)を，これに対応する医 歯大病理学教室における 120 例についての同様の 分類(石川, 1959) ${ }^{4)}$ に対比すると, 後者は次の如 くである。

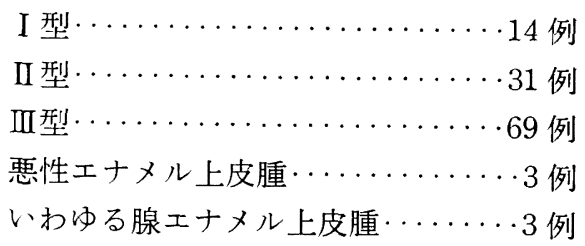

すなわち，北西ドイツ顎外科においては，I 型が 少く，一方 II 型が相対的に多かつた他，悪性エナ メル上皮腫が 1 例もみとめられなかつたことが特 徵的である。またその基本型とされている霬胞型 および充実型とにわけて観察すると，北西ドィッ 顎外科では，露胞型が 21 例， $66 \%$ ，充実型が 4 例， $12 \%$ ，そして混合型が 7 例， $22 \%$ であつた。 これに対し平出 ${ }^{5)}$ による医歯大口外の 108 症例で 
は，混合型がもつとも多く 62 例， $57 \%$ ，ついで 軣胞型が 32 例，30\%，そして充実型が 14 例，13 \%であつた。この検索に際して，混合型はその摘 出腫瘍の分割に際して遭遇する面により判定が著 るしく動摇する。その際, 混合型が霆胞型と混じ られる可能性の高いことを考虑に入れ，両者をあ わせてみると，霟胞一混合型が 94 例， $87 \%$ とな り，ほぼ北西ドイツ頡外科の症例群と同值 (27 例 $88 \%$ )になる。これはまた，Robinson 等の報告 ともおおむ极一致する。

いわゆる腺エナメル上皮腫について，医歯大口 外および病理では, 現在迄に計 5 例を発表(石川, 森6)，小守ほが7)しているが，北西ドィッ顎外科 では，本研究終了迄には 1 例しか見出されなかつ た。

悪性エナメル上皮腫の出現を，Schneider $(1957)^{13)}$ は，文献上に検索して 1 ないし $4 \%$ の頻 度で認め, 平出 ${ }^{5)}$ は医歯大口外の症例 115 例中に 5 例の悪性エナメル上皮腫を記載しているが，北 西ドイツ顎外科では 54 例中確実なる悪性エナメ ル上皮腫は 1 例もみとめられなかつた。ただ 1 例 のみが，初回の関節離断下顥骨切除を含む根治手 術にも拘わらず，6回の再発をくりかえし, 細胞学 的悪性像ならびに転移は示さないが，かなり高度 の腫瘍の浸潤性発育所見が観察された。この症例 の場合，再発が悪性エナメル上皮腫となんら無関 係であるとしても，エナメル上皮腫の治療にあた つての手術侵襲としては，十分にして確実なる腫 瘍の摘出切除が必須であることをわれわれに教え るものと考える。

その他, 石川(4), 森(1959) ${ }^{14)}$ らが詳細に研究発 表し，また Gorlin ほか(1961) ${ }^{15)}$ が，1 例を報告 している顆粒細胞の存在は，北西ドイッ顎外科の 54 例中，III型の 2 例に認められた。

\section{V. まとめ}

ハンブルグ大学, 北西ドイッ顎外科学教室にお けるエナメル上皮腫 54 例を, 前回報告の臨床統 計的考察にひきつぎ，その治療方法と予後および 組織学的所見等に検討を加え次の結果を得た。
北西ドイツ顎外科学教室におけるエナメル上皮 腫に対する治療方針は，原則的に東京医科歯科大 学口腔外科学教室のそれと一致する。両教室とも 第一に選択する療法は，広範なる下顎骨切除を含 む腫瘍摘出根治手術であつた。北西ドイッ頢外科 に㧍いて外科的に処置された 46 例中, 再発は 4 例， $9 \%$ であり，その 5 年絶対生存率は $61 \%$ で あつた。

54 例中 32 例について十分なる 標本材料と共に 組織学的検索を行ない,石川の分類を適用した。典 型的なエナメル上皮腫像を示す而型が最も多く， 21 例， $68 \%$ ，その他腺 エナメル上皮腫が 1 例み られた。確実なる悪性エナメル上皮腫は 1 例も見 出されなかつたが，1例は初回の根治手術にも拘 わらず，再発を 6 回くりかえし，腫湯組織の浸潤 性発育がみとめられた。

本研究は, Hamburg 大学付属病院 Nordwestdeutsche Kieferklinik に扝いて, 同主任 Herr Prof. Karl Schuchardt の好意ある許可のもとに行なわ机たことを記し 感謝します。本研究の病理学的所見について流，1962 年 9 月, 同研究室に滞在された本学病理学教室石川教授 より直接御指導，御教示いただいたものであり，さら に, 著者に本研究を行なら機会を与えられ御指導, 御 校閲下さつた上野教授に深く感謝の意を表します。

本論交の要旨は昭和 38 年 5 月 15 日, 口腔病学会例会 に执いて発表された。

\section{文献}

1) 清水正嗣：北西ドイツ顎外科学教室におけるエ ナメル上皮腫 54 例の臨床的および病理学的研 究. 第 1 報 臨床統計的観察および $\mathrm{X}$ 線学的所 見について. 口病誌, $30: 122$, 昭 38.

2) 宮崎吉夫 - 荒井元正 : 珐瑯上皮腫の組織由来に ついて. 口病誌, $13: 349,1939$.

3) Ishikawa, G. : A histopathological study of odontogenic tumors, Acta Pathologica Japonica, $7: 525,1957$

4) 石川梧朗：歯原腫瘍について，とくに病理学的 方面から (その 1). 口病誌, $26: 2108,1959$.

5）平出経布：エナメル上皮腫の臨床的ならびに病 理学的研究. 口外誌, 4:214, 1958.

6) Ishikawa, G. \& Mori, K: A histopathological study on the adenomatoid ameloblastoma, Report of four cases, Acta Odont. Scand. 20 : 
$419,1962$.

7）小守昭, 橋本幸, 金田敏郎ほか：所謂腺エナメル 上皮腫の1 例について. 口科誌, $12: 200,1963$.

8) Lösch, G., 清水正嗣 : 開咬症の Schuchardt 法 による外科・矯正的治療. 口病誌, $30 ： 59$, 昭 38 .

9) Robinson, H. B. G. : Ameloblastoma; a study of 379 cases, Arch. Path., 23 : 664, 1937.

10) Small, J. A., Waldron. C. A. : Ameloblastomas of the jaws. O. S., O. M. \& O. P., 8 : 281, 1955.

11) Pflüger, H. : Über die vom zahnbildenden Gewebe ausgehenden Geschwülste Adamantinom und Odontom, Dtsch. Z-M-Khlk., 25 : 97, 1956.
12) Langer, E. : Histopathologie der Tumoren der Kiefer und der Mundhöhle, Stutttgart, 1958, Georg Thieme Verlag.

13) Schneider, G. : Kritische Betrachtungen zur Frage der Malignität von Ameloblastomen, Dtsch. Z-M-Khlk. 27 : 146, 1957.

14）森勝好：エナメル上皮腫の 組織学的研究, 特に 2,3 の物質の組織化学的所見について. 口病誌, $26: 108$, 昭 34 .

15) Gorlin, R. J., Chaudhry, A. P. \& Pindborg, J. J. : Odontogenic tumors, classification, histopathology, and clinical behavior in man and domesticated animals, Cancer, $14: 73,1961$. 